\title{
The Potential Effect of Thymol from Black Seed Extract (Nigella Sativa) on Inhibiting the Growth of Candida albicans (Laboratory Studies in Leucorrhea Culture)
}

\author{
Nurul Aziza Ath Thaariq, Suharyo Hadisaputro, Supriyana \\ Applied Midwifery, Graduate Program, School of Health Polytechnics, \\ Ministry of Health Semarang
}

\begin{abstract}
Background: Leucorrhea is a complaint of reproductive health problems that are often experienced, $83 \%$ of cases are caused by Candida albicans. Candida albicans resistance to fluconazole (2.9\%) and itraconazole (5.4\%), so that antifungals from plant screening are safer and able to inhibit the growth of Candida albicans. This study aimed to explain the potential of thymol compounds in black cumin seed extract (Nigella sativa) various concentrations can inhibit the growth of Candida albicans.

Subject and Method: This was a randomized controlled trial. Study sample was Candida albicans culture divided into 5 groups. The dependent variable was growth of Candida albicans. The independent variable was thymol compounds of black cumin seed extract. The growth of Candida albicans were measured by calipers. The data was analyzed by one way ANOVA and post hoct.

Results: Thymol 12.5\% lowered the growth of Candida albicans 9.20 (mean= $-9.20 ; \mathrm{p}<0.001$ ).

Conclusion: Thymol compounds of black cumin seed extract has the potential as an alternative treatment for leucorrhea.
\end{abstract}

Keywords: thymol, black seeds, Candida albicans

\section{Correspondence:}

Nurul Aziza Ath Thaariq. Master of Applied of Midwifery, Health Polytechnics Ministry of Health Semarang. Jl. Tirto Agung, Pedalangan, Banyumanik, Semarang 50239, Central Java. Email: naziza.aththaariq@gmail.com. Mobile: +6285869522220

\section{BACKGROUND}

Leucorrhea (vaginal discharge) is a reproductive health complaint that is often experienced. About $75 \%$ of women in the world experience vaginal discharge at least once in a lifetime and as many as $45 \%$ of women experience vaginal discharge twice or more. As many as 70\% of Indonesian women have had leucorrhea (Erwhani, 2015). As many as $83 \%$ of the causes of vaginal discharge are Candida albicans which is widespread in women of childbearing age and comes from rural areas (Panda, Panda and Ramani, 2013).

Leucorrhea is a sign of vaginitis and chronic vaginal inflammation (Parate et al.,
2017). Leucorrhea is another early symptom of cervical cancer. Infection in reproductive health that is not immediately treated can cause infertility and increase the incidence of ectopic pregnancy (Manuaba, 2009).

Management of leucorrhea caused by Candida albicans can be pharmacologically or no pharmacologically. Pharmacological treatment using antifungal drugs. However, excessive use of antifungal drugs can trigger resistance. Candida albicans has shown resistance to fluconazole (2.9\%) and itraconazole 5.4\% (Shokohi et al., 2010; Dabas, 2013). Non-pharmacological management using black cumin seed extract, soursop leaf 
extract, beluntas leaf extract, betel extract, and beluntas leaf extract (Suwanti, 2016; Yuniarni and Lukmayani, 2015).

Plants are a source of thousands of active substances that can inhibit the growth of pathogenic microorganisms (Arif et al., 2009; Negri et al., 2014). Natural products with antifungal activity can be an alternative to combat multi resistant microorganisms and prevent contact of these microorganisms with synthetic products, thereby reducing the risk of new resistance or having a better mechanism (de Castro et al., 2015). Thymol is one of the terpene compounds that are widely produced by various types of plants, including black cumin. The content in black cumin seed extract was $26.8 \%$. Thymol functions as fungistatics by inhibiting ergosterol biosynthesis and disrupting membrane integrity (Ahmad et al., 2013; Taha etal., 2010; Vandeputte et al., 2012). The author wanted to prove thymol from black cumin seed extract (nigella sativa) from various concentrations potentially inhibiting the growth of Candida albicans.

\section{SUBJECTS AND METHOD \\ 1. Study Design \\ This was a randomized control trial. The study was conducted at Health Laboratory of Central Java Provincial, from May 2018 to June 2018.}

\section{Study Sample}

Samples were Candida albicans cultures from vaginal swabs of leucorrhea patients.

\section{Study Variables}

The dependent variable was the inhibitory power of Candida albicans growth. The independent variable was thymol cumin seed extracts with various concentrations.

\section{Operational Definition of Variables}

Thymol extract of black cumin seeds is the result of extraction obtained by extracting the active ingredient of black cumin seeds with maceration techniques for the separation of thymol compounds with a concentration of $12.5 \% ; 25 \% ; 50 \%$; and $100 \%$. Data have an ordinal scale. The growth of Candida albicans is the inhibitory growth of Candida albicans at each concentration. Data is obtained by observing clear zones formed by using calipers.

\section{Study Instruments}

Data is obtained from primary data. Data is obtained by observing clear zones formed by using calipers.

\section{Data Analysis}

The data were analyzed by one way ANOVA and Post Hoc test to determine whether there was a difference in the inhibitory growth of Candida albicans between the positive control group, negative control group and the intervention group with various types of thymol compound concentration from black cumin extract.

\section{Research Ethics}

The ethical clearance was registered at the Ethics Committee of the Health Polytechnic Semarang and was declared as worthy of ethics based on decision letter number: 426 / KEPK / Poltekkes-Smg / EC / 2018.

\section{RESULT}

\section{Study Subject Characteristics}

Candida albicans culture is obtained from vaginal discharge. Vaginal secret swabs are obtained from patients who experience signs and symptoms of removing a lot of mucus, are colored, and cause unpleasant odors. Further morphological identification of Candida albicans culture was done to avoid testing errors. Fungi cultured showed spherical morphological features with a slightly convex surface, smooth, slippery and slightly multiple, especially in older colonies. The color of the colony is yellowish white and smells sour like aroma tape. Gram staining shows purple (gram-posi- 
tive) and shows fermentation and gas reactions in glucose and maltose, and fermentation occurs without producing gas on sucrose.

\section{Univariate Analysis}

Table 1 shows that there are a difference in the mean diameter of the growth inhibition zone of Candida albicans which shows the difference in antifungal potential in each treatment group. The measurement results showed that thymol compounds at a concentration of $12.5 \%$ produced the smallest growth inhibition zone of Candida albicans, namely $12.8 \mathrm{~mm}$ and a concentration of $100 \%$ produced the largest inhibitory zone of $\mathbf{2 2 . 2 0}$.

Based on Table 1, then a figure is made which illustrates the average diameter of the zone of growth inhibition of Candida albicans in each treatment group.

Table 1. Diameter of the Inhibitory Zone

\begin{tabular}{ccccccc}
\hline \multirow{2}{*}{ Treatment } & \multicolumn{7}{c}{ Formed Inhibition Zone (mm) } & \multirow{2}{*}{ Mean } \\
\cline { 2 - 6 } & I & II & III & IV & V & \\
\hline Thymol 12.5\% & 12 & 13 & 14 & 13 & 12 & 12.80 \\
\hline Thymol 25\% & 14 & 14 & 15 & 15 & 16 & 14.80 \\
\hline Thymol 50\% & 20 & 19 & 21 & 20 & 19 & 19.80 \\
\hline Thymol 100\% & 22 & 21 & 23 & 23 & 22 & 22.20 \\
\hline Flukonazole & 23 & 21 & 23 & 21 & 22 & 22.00 \\
\hline Ethanol & O & O & O & O & O & O \\
\hline
\end{tabular}

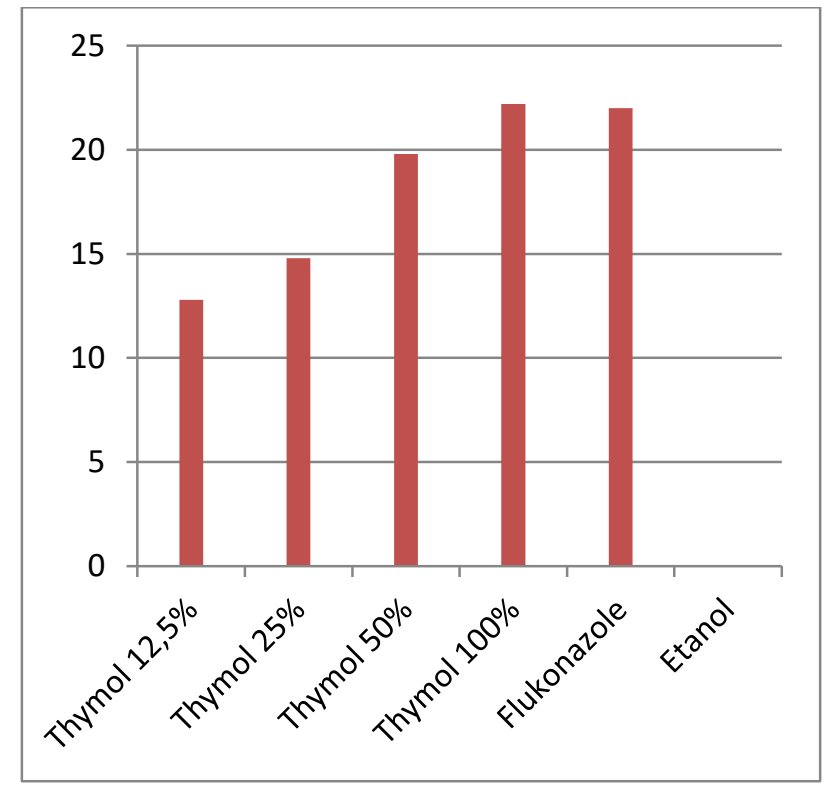

Figure 1. Graph of average diameter of inhibitory power of growth of Candida albicans

Figure 1 shows the inhibitory power of thymol compounds on the smallest growth of Candida albicans at a concentration of 12.5\% and the largest at a concentration of $100 \%$, which means that the greater the concentration of thymol compounds given, the greater the growth inhibition zone of the formed Candida albicans.

\section{Bivariate Analysis}

Table 2 shows that the $\mathrm{p}$ value for the One Way ANOVA test is 0.000 , which means that there are at least significant differences in the inhibitory growth of Candida 
albicans in the two groups. To find out which groups there were significant differences, the Post Hoc analysis test was conducted.

Table 2. The inhibitory power of growth of Candida albicans between treatment groups

\begin{tabular}{lccc}
\hline Inhibitory Power & N & Mean \pm SD & p \\
\hline Thymol 12.5\% & 5 & $12.80 \pm 0.84$ & $<0.001$ \\
Thymol 25\% & 5 & $14.80 \pm 0.84$ & \\
Thymol 50\% & 5 & $19.80 \pm 0.84$ & \\
Thymol 100\% & 5 & $22.20 \pm 0.84$ & \\
Flukonazole & 5 & $22.00 \pm 1.00$ & \\
Ethanol & 5 & $0,80 \pm 0.84$ & \\
\hline
\end{tabular}

Table 3. Intergroup Data Comparison Results Treatment

\begin{tabular}{|c|c|c|c|c|}
\hline \multirow[t]{2}{*}{ Inhibitory Power } & \multirow{2}{*}{$\begin{array}{c}\text { Mean } \\
\text { difference }\end{array}$} & \multicolumn{2}{|c|}{ 95\% CI } & $\mathbf{p}$ \\
\hline & & Lower limit & Upper limit & \\
\hline Thymol $12.5 \%$ vs. Flukonazole & -9.20 & -10.23 & -8.16 & $<0.001$ \\
\hline Thymol 25\% vs. Flukonazole & -7.20 & -8.23 & -6.16 & $<0.001$ \\
\hline Thymol 50\% vs. Flukonazole & -2.20 & -3.23 & -1.16 & $<0.001$ \\
\hline Thymol 100\% vs. Flukonazole & 0.20 & -0.83 & 1.23 & 0.695 \\
\hline
\end{tabular}

From table 3 the results of the comparison of the growth inhibition of Candida albicans between the treatment groups above can be seen that there was a significant difference between the $12.5 \%$ thymol group and $25 \mu \mathrm{g}$ fluconazole with an average difference of -9.20 . This shows that the $25 \mu \mathrm{g}$ fluconazole inhibitory effect on the growth of Candida albicans is better than thymol from the extract of black cumin seeds with a concentration of $12.5 \%$.

There was a significant difference between the $25 \%$ thymol group and $25 \mu \mathrm{g}$ fluconazole with an average difference of 7.20. This shows that the $25 \mu \mathrm{g}$ fluconazole inhibitory effect on the growth of Candida albicans is better than thymol from black cumin seed extract with a concentration of $25 \%$.

There was a significant difference between the 50\% thymol group and $25 \mu \mathrm{g}$ fluconazole with an average difference of 9.20. This shows that the $25 \mu \mathrm{g}$ fluconazole inhibitory effect on the growth of Candida albicans is better than thymol from $50 \%$ cumin seed extract.
In the $100 \%$ thymol group there was no significant difference compared to the fluconazole group which means that there was no significant difference in the average inhibitory growth of Candida albicans in the $100 \%$ thymol group with the fluconazole group. This shows that the inhibitory power of thymol compounds in cumin seed extract with a concentration of $100 \%$ on the growth of Candida albicans is the same as fluconazole $25 \mu \mathrm{g}$.

\section{DISCUSSION}

The results showed that thymol compounds from black cumin extract were shown to inhibit the growth of Candida albicans after being exposed for 24 hours. Previous study has suggested that black cumin has a broad antimicrobial spectrum, including gram-negative bacteria, gram-positive bacteria, viruses, parasites and fungi (Ahmad et al., 2013; Prastiwi et al., 2015). Another study also stated that black cumin seed extract was effective in inhibiting the growth of Candida albicans in heat cured acrylic resin (Hanoem et al., 2011).This 
shows that one of the compounds contained in black cumin seed extract has antifungal activity, one of which is inhibiting fungal growth of Candida albicans.

Table 1 shows that thymol compounds with various concentrations can inhibit the growth of Candida albicans. Antifungal activity is categorized as having weak sensitivity if the diameter of the inhibitory power formed is $10-15 \mathrm{~mm}$, categorized as having moderate sensitivity if the diameter of the inhibitory power formed is 16-20 $\mathrm{mm}$, and is categorized as having a strong sensitivity if the diameter of the inhibitory power formed is $>\mathbf{2 0} \mathrm{mm}$ (Prastiwi, 2008).

Based on the categorization, the thymol compound from extracts of black cumin seeds with a concentration of $12.5 \%$ and $25 \%$ had a weak inhibition; thymol compounds from black cumin seed extract with a concentration of $50 \%$ had moderate inhibitory power; and thymol compounds from black cumin seed extract with a concentration of $100 \%$ have strong inhibitory power. This is in line with the initial hypothesis where the results of the study showed that thymol compounds from black cumin seed extract with a higher concentration were greater in inhibiting the growth of Candida albicans.

The inhibitory power of thymol compound from the smallest black cumin extract was found in the lowest variation group, namely thymol group $12.5 \%$. The average inhibitory power of Candida albicans growth in the $12.5 \%$ thymol group was $12.8 \mathrm{~mm}$ which means that it was included in the category of weak inhibitory power. Previous research stated that the antifungal activity of thymol compounds began to be effective at a dose of 100-125 $\mathrm{mg} / \mathrm{L}$ (Ahmad et al., 2011). Another study stated that thymol with a concentration of $400 \mu \mathrm{g} / \mathrm{mL}$ was significantly able to reduce the proper number of Candida albicans cells, reducing up to $82 \%$ of the biofilm mass formed by Candida albicans which was tested on suppression fungi on the surface of acrylic resin which mimicked the surface of dentures(de Vasconcelos et al., 2014). Negative control groups are given ethanol. This aims to find out that ethanol does not have antifungal effects on Candida albicans. The results showed no inhibition zone diameter and Candida albicans grew well around the wells. This means that 70\% ethanol does not have antifungal effect on Candida albicans. Positive control used in this study is fluconazole, where fluconazole has been shown to inhibit the growth of Candida albicans.

Table 3 shows that there is no significant difference in the average inhibitory growth of Candida albicans in the 100\% thymol group with the fluconazole group. This shows that the 100\% thymol compound from black cumin seed extract has the equivalent ability of $25 \mu \mathrm{g}$ fluconazole in inhibiting the growth of Candida albicans, which means thymol compounds with a concentration of $100 \%$ can be used as alternative therapy in cases of leucorrhea caused by Candida albicans. The mechanism of action of fluconazole and thymol compounds as fungi statics is inhibiting ergosterol biosynthetic and disrupting membrane integrity (Ahmad et al., 2013; Taha et al., 2010).

The mechanism of thymol compounds capable of inhibiting the growth of Candida albicans is inhibiting ergosterol biosynthesis and disrupting membrane integrity at the adhesion stage (Ahmad et al., 2013; Taha et al., 2010). Candida albicans infection with host cells is divided into three stages, namely adhesion, invasion, biofilm formation and induction of tissue damage. In the adhesion stage, there is interaction of the cell wall of Candida albicans in the host cell. The first part of the Candida albicans 
that interacts with the host cell is the cell wall. Physical attachment and contact between Candida albicans and host cells further activates mitogen activated protein kinase as part of the integrity pathway activated by stress on the cell wall (where Candida albicans and host cells come into contact). In addition to activation of Mapkinases, at almost the same time there is an actin rearrangement in the host cell (Emerson and Camesano, 2014). After adhesion is invasion, hyphae Candida albicans penetrate into the surface of the epithelium, especially in cell junction along with the internalization of yeast cells (Naglik et al., 2014; Gow and Hube, 2012). The next stage is biofilm formation. Biofilm is a microbial colony that forms an organic polymer matrix that can serve as a marker of microbial growth. The biofilm can act as a protector so that the microbes that form biofilms usually have resistance to ordinary antimicrobials or avoid the immune system of the host cell. Fungal cells will proliferate to form colonies which cause inflammatory reactions and induce host tissue damage (Naglik et al., 2014; Lim et al., 2012).

At the adhesion stage in the pathogenesis of the infection is affected by the fungal cell wall. The Candida albicans cell wall functions as a protector and is also the target of several antimycotics. Cell walls play a role in the attachment and colonization process and are antigenic. Candida albicans cell membranes like other eukaryotic cells consist of multiple phospholipid layers. This membrane protein has enzyme activity such as manan synthase, chitin synthase, glucan synthase, ATPase and proteins that transport phosphate. The fungal cell wall consists of a phospholipid double layer. This layer contains a sterol compound called ergosterol. Ergosterol plays an important role in maintaining the permeability and integrity of the fungal cell wall and as an antimitotic target and is likely the place where enzymes that play a role in the synthesis of walls work (Emerson and Camesano, 2014). Thymol as an antifungal works in inhibiting synthetic ergosterol so that thymol can inhibit the mechanism of infection of the adhesion stage. The inhibition of ergosterol biosynthesis and disruption of membrane integrity causes inhibition of Candida albicans growth and the mechanism of leucorrhea infection is severed. Thymol compounds of black cumin seed extract have the potential as fungicides against Candida albicans in cases of leucorrhea.

\section{AUTHOR CONTRIBUTIONS}

Nurul Aziza Ath Thaariq selected the study subjects, collected the data, measured the growth of Candida albicans, and wrote the manuscript. Suharyo Hadisaputro gave theoretical suggestion on the effect of the effect of Thymol from Black Seed Extract (Nigella Sativa) on the growth. Supriyana did the data analysis and interpreted the results of data analysis.

\section{CONFLICT OF INTEREST}

We declare that we do not have any conflict of interest.

\section{FUNDING AND SPONSORSHIP}

This study used the authors' independent fund.

\section{ACKNOWLEDGEMENT}

We would like to thank to the laboratory and School of Health Polytechnics, Ministry of Health Semarang for giving permission to do this study.

\section{REFERENCE}

Ahmad A, Khan A, Akhtar F, Yousuf S, Xess I, Khan LA, Manzoor N (2011). Fungi- 
cidal activity of thymol and carvacrol by disrupting ergosterol biosynthesis and membrane integrity against candida. European Journal of Clinical Microbiology and Infectious Diseases, 30(1): 41-50. doi: 10.1007/s10096010-1050-8.

Ahmad A, Husain A, Mujeeb M, Khan SA, Najmi AK, Siddique NA, Damanhouri ZA, Anwar F (2013). A Review on Therapeutic potential of Nigella Sativa: A Miracle Herb. Asian Pacific Journal of Tropical Biomedicine, 3(5): 337-352. doi: 10.1016/S2221-1691(13)60075-1.

Arif T, Bhosale JD, Kumar N, Mandal TK, Bendre RS, Lavekar GS, Dabur R (2009). Natural products - Antifungal agents derived from plants. Journal of Asian Natural Products Research, 11(7): 621-638. doi: 10.1080/10286020902942350.

de Castro RD, de Souza TM, Bezerra LM, Ferreira GL, Costa EM, Cavalcanti AL (2015). Antifungal activity and mode of action of thymol and its synergism with nystatin against candida species involved with infections in the oral cavity: An in vitro study. BMC Complementary and Alternative Medicine. 15(1): 1-7. doi: 10.1186/s12906-0150947-2.

Dabas PS (2013). An approach to etiology, diagnosis and management of different types of candidiasis. Journal of Yeast and Fungal Research, 4(6): 6374. doi: 10.5897/JYFR2013.0113.

Hanoem EH, Imam B, Purnama K, Pranoto KP (2011). The effectiveness of Nigella Sativa seed extract in inhibiting Candida albicans on heat cured acrylic resin. Dental Journal (Majalah Kedokteran Gigi), 44(3): 137. doi: 10.20473/j.djmkg.v44.i3.p137-140.
Emerson RJ, Camesano TA (2014). Nanoscale investigation of pathogenic microbial adhesion to a biomaterial. Applied and Environmental Microbiology, 70(10): 6012-6022. doi: 10.1128/AEM.70.10.6012-6022.2004.

Erwhani Indri (2015). Relationship of knowledge about vaginal discharge (Flour albous) with an attitude of maintaining the cleanlines of the external genitalia while vaginal discharge (Flour albus) grade $5 \mathrm{M}$ and 6M in Elemetary School. 4(2): 36-44. Available at: http://journal.stikmuhptk.ac.id/index.php/jkk/article/view/ $32 / 29$.

Gow NAR, Hube B (2012). Importance of the Candida albicans cell wall during commensalism and infection. Current Opinion in Microbiology. Elsevier Ltd, 15(4): 406-412. doi: 10.1016/j.mib.2012.04.005.

Lim CS, Rosli R, Seow HF, Chong PP (2012). Candida and Invasive Candidiasis: Back to Basics. European Journal of Clinical Microbiology and Infectious Diseases, 31(1): 21-31. doi: 10.1007/s10096-011-1273-3.

Manuaba IGB (2009). Memahami Kesehatan Reproduksi Wanita. Jakarta: EGC.

Naglik JR, Richardson JP, Moyes DL (2014). Candida albicans Pathogenicity and Epithelial Immunity. PLoS Pathogens, 10(8): 8-11. doi: 10.1371/journal.ppat.1004257.

Negri M, Salci TP, Shinobu-Mesquita CS, Capoci IR, Svidzinski TI, Kioshima ES (2014). Early state research on antifungal natural products. Molecules, 19(3): 2925-2956. doi: 10.3390/molecules19032925.

Panda S, Panda SS, Ramani TV (2013). Incidence of candidiasis and trichomoniasis in leucorrhoea patients incidence of candidiasis and trichomo- 
niasis in leucorrhoea patients. IJCRR. 5(3): 92-96.

Parate SN, Gupta A, Wadadekar A (2017). Cytological Pattern of Cervical Smears in Leucorrhea. 4(10). doi: 10.17354/ijss/2017/17.

Prastiwi R, Iqbal A, Kristi A (2015). Aktivitas Imunomodulator Ekstrak nHeksana, Etil Asetat, dan Metanol Biji Jinten Hitam (Nigella sativa L.). Journal of Pharmaceutical Science and Pharmacy Practice. 2(2): 45-49.

Prastiwi ST (2008). Pemanfaatan mikroorganisme sebagai indikator uji. Jakarta: Erlangga.

Suwanti S (2016). Keputihan pada wanita usia subur menggunakan ekstrak daun sirsak. J Kebidanan dan Kesehatan Tradisional, 1(1): 69-73. Available at: http://jurnal.poltekkes-solo.ac.id/index.php/JKK/article/view/186/165.

Taha M, Azeiz A, Saudi W (2010). Antifungal effect of thymol, thymoquinone and thymohydroquinone against yeasts, dermatophytes and non-dermatophyte molds isolated from skin and nails fungal infections. Egyptian Journal of Biochemistry and Mole- cular Biology, 28(2). doi: 10.4314/ejbmb.v28i2.60802.

Shokohi T, Bandalizadeh Z, Hedayati MT, Mayahi S (2010). In vitro antifungal susceptibility of candida species isolated from oropharyngeal lesions of patients with cancer to some antifungal agents. Jundishapur Journal of Microbiology, 4(1): 19-26. doi: 10.1016/j.jconhyd.2010.08.009.

Vandeputte P, Ferrari S, Coste AT (2012). Antifungal resistance and new strategies to control fungal infections. International Journal of Microbiology. doi: 10.1155/2012/713687.

de Vasconcelos LC, Sampaio FC, Albuquerque AJ, Vasconcelos LC (2014). Cell viability of Candida albicans against the antifungal activity of thymol. Brazilian Dental Journal, 25(4): 277-281. doi: 10.1590/01036440201300052.

Yuniarni U, Lukmayani Y (2015). Antifungal activity of pluchea indica, coleus scutellarioides, piper betle and their combination extracts against Candida albicans. FMIPA Universitas Islam Bandung. 89-94. Available at: http://jurnal.poltekkes-solo.ac.id/index.php/JKK/article/view/186/165. 